\title{
UTILIZATION INTERCROPPING IN THE REDUCTION OF THE TWO SPOTTED SPIDER MITE Tetranychus urticae $\mathrm{KOCH}$, INFESTING KIDNEY BEAN. \\ Allam, S. A. \\ Plant Protection Res. Institute, Agric. Res. Center, Dokki, Giza, Egypt.
}

\begin{abstract}
In Menoufiya Governorate, a field experiment was conducted as a completely randomized design, in spring period during the two successive season 2010 and 2011 using Kidney bean plantation. four different treatment were conducted as :Kidney bean plants alone in addition to the same plant intercropped on Mint, Fennel and Black cumin. The main crop, Kidney bean, plants were sown on 4 different spaces i.e.10, 20, 30 and $40 \mathrm{~cm}$. Kidney bean plants were investigated for abundance of the different stages of the two spotted spider mite Tetranychus urticae Koch :eggs, immatures and adults, as wells their predators Phytosiulus persimilis Athias-Henriot Euseius scutaulis Athias-Henriot (Family: Phytoseiidae). Inspection and investigation was conducted every two weeks: $15,30,45,60,75$ and 90 days from sowing. Results showed that the mean values of $T$. urticae during the growth period clearly increased in the space of $10 \mathrm{~cm}$ between plants while the reverse trend occurred with the space $40 \mathrm{~cm}$. Results showed also, there was a significant difference between the mean numbers of eggs, immatures and adults of Tetranychus urticae Koch infesting Kedney bean in different spaces during sowing.

Keywords : Intercropping, mites, Aromatic plants, Kidney bean.
\end{abstract}

\section{INTRODUCTION}

There is a high importance for the vegetable crops in Egypt, especially the Kidney bean Phaseolus vulgaris L., as it is one of high protein cntent in addition to an economic importance for the farmers in Delta area, Egypt. Many pests attack this crop in the field e.g. Tetranychus urticae koch.There are many evidence on the effect of using Phytosiulus persimilis AthiasHenriot (Family: Phytoseiidae) to control the two spotted mite Tetranychus urticae Koch in many vegetable crops especially Kidney Bbeans (Conference Proceedings 2004). Intercropping two crop in the same field proved its efficiency to minimize the pest population, in the same time getting additional.In Bulgaria, Mateeva et al (1998) studied the effect of intrercropping in same vegetable crops to control pests. Some Egyptian workers investigated the effect of sowing spacing in some vegetable (Conference Proceeding 2004). The present current study aimed to throw light on role of intercropping in controlling the two spotted spider mite $T$. urticae to achieve safe agriculture environment.

\section{MATERIALS AND METHODS}

In Menoufiya Governorate, a field experiment was conducted as a completely randomized design, in spring period during the two successive season 2010 and 2011 in Kidney bean plantation. The 4 different treatment 
Allam, S. A.

were :Kidney bean plants alone addition to the same plant intercropped on Mint, Fennel and Black cumin. The main crop, Kidney bean, plants were sown on 4 different spaces each others: $10,20,30$ and $40 \mathrm{~cm}$. Kidney bean plants were investigated for abundance of the different stages of the two spotted spider mite Tetranychus urticae Koch :eggs, immatures and adults, as wellas their predators Phytosiulus persimilis Athias-Henriot Euseius scutaulis Athias-Henriot (Family: Phytoseiidae). Inspection and investigation was conducted after every two weeks: $15,30,45,60,75$ and 90 days from sowing. The first 3 dates of inspections was considered as (growth period), while the last 3 inspection considered as : (fruiting period). Ten (10) leaflets were taken randomly from each replicate and directly transferred to the laboratory and investigated using the stereoscopic binocular microscope. The agricultural practices were done as normal in the similar field crop. The mean values of the different stages of the mites and their predators were tabulated and statistically analyzed.

\section{RESULTS AND DISCUSSION}

Allam et al (2009) studied the effect of intercropping of four Aromatic plants on the population of three main pests and their associated predators with three bean varieties at Fayoum and Gharbia Governorates, Egypt, they proved that each of Mint, Fennel and Black cumin played an important role to reduce population of $T$. urticae on Phaseolus vulgaris in Gharbia and Fayom Governorates. Several studies were conducted in and out of Egypt on the intercropoing of several crops on pests infestation (Hassan et al., 1989; Omar et al., 1993\&1994; Mateeva et al., 1998; Habashi, 2000; Megali et al., 2000; Rizk, 2000; Rizk and Mikhail, 2000, Rizk et al., 2002 Kong et al., 2005 and Abou-zaid (2007). In this study, table (1): showed that the data of the mean values of $T$. urticae during the growth period clearly increased in the space of $10 \mathrm{~cm}$ between plants, as they recorded 69.37, 47.87 and 48.17 individuals for the eggs, immature and adult respectively, while it were $16.00,15.20$ and 15.87 individuals in case of $40 \mathrm{~cm}$ between plants in control treatment. This trend was confirmed in the other treatments as it recorded 11.50, 6.92 and 4.04 individuals in $10 \mathrm{~cm}$ space against $6.21,6.75$ and 5.08 individuals in $40 \mathrm{~cm}$ space in case of intercropped on mint. These values again recorded 6.54,4.54 and 3.67 against 6.42, 5.17 and 3.04 and 6.88,4.08 and 2.00 against $6.33,4.08$ and 2.88 individuals in 10 and $40 \mathrm{~cm}$ space for Fennel and Black cumin respectively. Data of statistical analysis in table (3): showed that there was a significant difference between eggs 18.66 and both of the immature stages and adults 12.59 and 11.76 respectively. In the same time, density of both $T$. urticae and predators showed significant difference between the control (26.56) and other treatments, since the density of mites during intercropping mint had (5.60)and each of Fennel and Black cumin 3.67 and 3.86 individual respectively. 
J. Plant Prot. and Pathology, Mansoura Univ., Vol. 2 (6), June, 2011

1

647 
Allam, S. A.

2 
$\mathrm{n}$ respect of Fruiting period, table (1) and Fig (1): revealed that the values represent the mites stages showed the same trend in different crops, as the eggs, immature and adult individual recorded $62.07 .45 .50 \quad \& 41.6$ against16.60,17.27 \& 17.83 and $11.50,6.92 \& 4.04$ against $6.21,6.75 \& 5.08$ and $6.72,4.56 \& 3.72$ against $6.60,5.32 \& 3.08$ and $6.88,4.08 \& 2.00$ against $6.33,4.08 \& 2.88$ in $10 \mathrm{~cm}$ against $40 \mathrm{~cm}$ space between plants in Kidney bean alone (control) and intercropped on Mint, Fennel and Black cumin respectively. Values of 20 and $30 \mathrm{~cm}$ space showed intermediate and transitional values between the pre-mentioned values of 10 and $40 \mathrm{~cm}$.

A

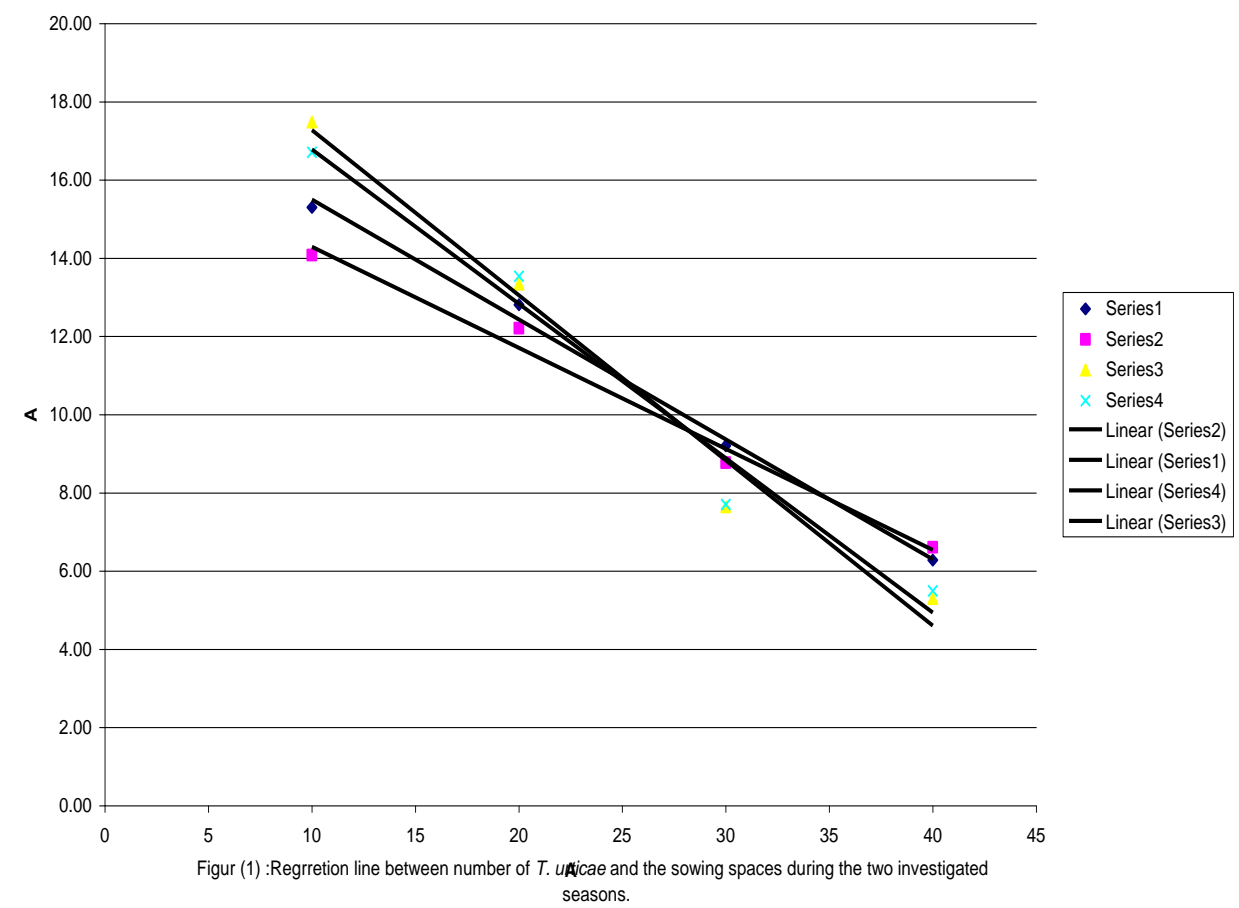

Regression line (Figure1) showed the linear relationship between mite density and decreasing the space between plants. Data of statistical analysis in table (3): also shows that there was a significant difference between the three components of $T$. urticae :eggs (17.76), immatures (12.50) and adults 10.80 individuals respectively. About intercropping there was no difference between Fennel (3.74) and black cumin (3.86) individuals but the both showed significant difference between each of the control (Kidney bean alone) 25.08 and the mint 5.60 individuals respectively. Table (1) also indicate the abundance of the predators in the first season : $p$. persimilis and $E$. scutaulis together. their mean values show the same trend as of $T$. urticae as their density was approximately 2 folds in the narrow space plantation $(10 \mathrm{~cm}$ space) against the wide space plantations $(40 \mathrm{~cm})$. Predators mean 
Allam, S. A.

value during the growth period $0.83,0.71,071$ and 0.75 against $0.43,0.46$, 0.38 and 0.67 individuals in the plantations of $10 \mathrm{~cm}$ and $40 \mathrm{~cm}$ spaces for the control, Mint, Fennel and Black cumin respectively. During the fruiting period, the density of the predators was clearly affected with the spaces between plants, the same table (1), indicated that their abundance under $10 \mathrm{~cm}$ space

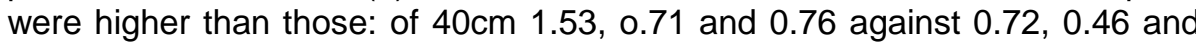
0.44 individuals for the control. Mint and Funnel treatments, while in the Black cumin their was slight increase in the narrow space plantations $(10 \mathrm{~cm})$ as the density recorded 0.75 individuals against 0.67 under $40 \mathrm{~cm}$. Again the same table and figure (1): shows that the mean values of the predators in the plantation of 30 and $20 \mathrm{~cm}$ were intermediate and transitional values between the above mentioned values in both and fruiting period. In the recent study, it was noticed that the weak abundance of the predators e.g. Phytoseiulus persimilis , Jackal and Schmidt in Germany (1999) noticed that mortality of these predators increased as a result of using Fennel extract. The same trend of the result data in table (1) was again confirmed in table (2): as the density of both mites and their predators were higher in the narrow space plantation (10) than those of the wider spaces 20,30 and $40 \mathrm{~cm}$. There was a significant differences between the density values under the different treatments :control, Mint, Funnel and Black cumin as appeared in the first season. Also, the different stages of the mites : eggs, immatures and adults were different clearly as appeared in the previous season. Mateeva et al. 1998) proved that the density of some pests including $T$. urticae was significantly reduced under intercropping compared with the sole crop. Table (3) shows that there was significant difference between the four treatments during the growth period they recorded 26.12, 6.96, 5.20 and 2.19 individuals for the control, Mint, Fennel and Black cumin.

Table (3): The statistical analysis of the mean values of mites during the two season under the 4 different

\begin{tabular}{|c|c|c|c|c|c|}
\hline \multirow{2}{*}{\multicolumn{2}{|c|}{ Parameter }} & \multicolumn{2}{|c|}{ Season 1} & \multicolumn{2}{|c|}{ Season 2} \\
\hline & & Growth & Fruiting & Growth & Fruiting \\
\hline \multirow{4}{*}{ Crop } & Control & $26.56 a$ & $25.08 a$ & $26.12 \mathrm{a}$ & $24.18 a$ \\
\hline & MINT & $5.60 b$ & $5.60 b$ & $6.96 \mathrm{~b}$ & $7.49 b$ \\
\hline & FUNL & $3.67 c$ & $3.74 c$ & $5.20 c$ & $3.32 c$ \\
\hline & BLACK & $3.86 c$ & $3.86 c$ & $2.19 d$ & $7.82 b$ \\
\hline \multirow{3}{*}{ INSPC } & 1 & $8.81 b$ & $9.82 b$ & $11.68 \mathrm{a}$ & $12.15 a$ \\
\hline & 2 & $11.59 a$ & $10.19 a b$ & $10.39 a$ & $10.24 b$ \\
\hline & 3 & $12.30 \mathrm{a}$ & $11.26 \mathrm{~b}$ & $10.76 a$ & $10.20 \mathrm{~b}$ \\
\hline \multirow{4}{*}{ STAGE } & EGGS & $18.66 \mathrm{a}$ & $17.76 a$ & $17.40 \mathrm{a}$ & $16.31 \mathrm{a}$ \\
\hline & IMMATURES & $12.59 \mathrm{~b}$ & $12.50 \mathrm{~b}$ & $12.50 \mathrm{~b}$ & $13.75 b$ \\
\hline & ADULT & $11.76 \mathrm{~b}$ & $10.80 c$ & $10.80 c$ & $12.97 \mathrm{~b}$ \\
\hline & PREDETORS & $0.59 c$ & $0.62 d$ & $0.62 d$ & $0.42 c$ \\
\hline \multirow{4}{*}{ SPACE } & $10 \mathrm{~cm}$ & $15.30 \mathrm{a}$ & $14.07 a$ & $17.48 \mathrm{a}$ & $16.71 \mathrm{a}$ \\
\hline & $20 \mathrm{~cm}$ & $12.81 \mathrm{~b}$ & $12.20 b$ & $13.34 b$ & $13.53 b$ \\
\hline & $30 \mathrm{~cm}$ & $9.20 c$ & $8.77 c$ & $7.64 c$ & $7.70 \mathrm{c}$ \\
\hline & $40 \mathrm{~cm}$ & $6.28 d$ & $6.61 d$ & $5.30 d$ & $5.49 d$ \\
\hline
\end{tabular}


Also, the same significant difference between the values of both the mites and predators under the different spaces :17.48, 13.34, 7.64 and 5.30 individuals was appeared. The same table individuals that there was no any difference between the inspection each others : 11.86, 10.39 and 10.76 individuals. Different stages of the mites showed a significant difference between each other : 17.40, 12.50 and 10.80 individuals for eggs, immatures and adults respectively. In respect of the fruiting period of the second season the same table (3) showed that, there was significant difference between the control and Fennel from one hand, and between control and both of Mint and Black cumin from the other hand. The values of mean abundance of both mites and predators under the different 4 spaces were significantly different : $16.71,13.54,7.71$ and 5.49 individuals for $10,20,30$ and $40 \mathrm{~cm}$ respectively. Number of eggs 16.31 significantly increased than each of immatures and adults 13.75 and 12.97 individuals respectively.

\section{REFERENCES}

Abou-Zaid, A.M.(2007).Studies on some mites infesting cucumber crop with the application of some IPM aspects. Ph.D. Thesis, Zoology Dept., Fac. of Science for Girls, Al-Azhar Univ.,204 p.

Allam, S.A.; Nadia H. Habashi, H. M. Neinaei and E.M.A. Yassin.(2009) Effect of intercropping of four aromatic plants on the population of three main pests and their associated predators with three Bean varieties a Fayoum and Gharbia Governorates, Egypt. Minufya J. Agric. Res. 34 No. 1(2):215-230.

Conference PrOceeding (2004) Second International Conference of Organic Agriculture, 'Healthy food for every one', Cairo, Egypt, 25- 27 March, Egyptian Journal of Agricultural Research 82: 2 (Special Issue), 256

Habashi, N. H. (2000). Using alternatives to pesticides for the control mites infesting some vegetable plants. Ph.D. Thesis, Inst. of Environ. Studies and Res., Ain Shams Univ., 183 pp.

Hassan, A. A., F. M. Hoda, M. M. El-Beheiry and A. M. Mostafa (1989). Intercropping effect of maize and soybean on spider mite, Tetranychus cucurbitacearum (Sayed) infestation and yield. Proc. $1^{\text {st }}$ Int. Conf., Econ.

Jackel, B.; Schmidt, H. U. (1999) Plant extracts: possibilities and limitations. 2. Reduction of damage by pests and effects of plant extracts on nontarget organisms. Gesunde Pflanzen. 51: 4, 101-108.

Kong, C. H., F. Hu, X. H. Xu, M. X. Zhang and W.J. Liang (2005). Volatile allelochemicals in the Ager atum conzoides intercropped citrus orchard and their effects on mites Amblyseius newsami and Panonychus citri. J. Chem. Ecol., 31 (9): 2193-2203.

Mateeva, A., D. Svetleva, S. Stratieva and D. Andonov (1998). Influence of intercropping of maize, onion, garlic and bean on population density of some bean pests. 63 (b): 507-510. 
Allam, S. A.

Megali, M. K., S. M. Hafez and N. H. Habashi (2000). Effect of intercropping bean plant with different crops on two tetranychid mites population and on bean crop. J. of Environ. Sci., 1 (2): 719-734.

Omar, H. I. H., M. F. Haydar and A. E. M. El-Sorady (1993). The impact of intercropping and cowpea on pest infestation. Egypt. J. Agric. Res., 71 (3): 709-716.

Omar, H. I. H., M. F. Haydar and A. E. M. El-Sorady (1994). Effect of sowing date of intercropping cowpea with cotton on infestation with some major pests. Egypt. J. Agric. Res., 72 (3) : 691-698.

Rizk, M.A. (2000). The effect of certain medicinal plants (coriander) intercropping with tomato in reducing pest infestation in Fayoum, Egypt. Proc. of the Egypt Conference on Medicinal and Aromatic Plant and 3 Millennium, 21-22 No., pp. 132-152.

Rizk, M. A. and W. Z. Mikhail (2000). Relationships of irrigation regimes and intercropping with pest infestation of tomato in Fayoum, Egypt. Egypt. J. Zool., 35 : 361-371.

Rizk, M. A., A. K. F. Iskandar, L. S. Sourial and N. H. Habashy (2002). Effect of intercropping of guar (Leguminosae) (Cyompois tetragonolaba) with tomato on level infestation of sucking pests infesting tomato. $2^{\text {nd }}$ Inter. Conf., Plant Prot. Res. Inst., Cairo, Egypt, Vol. I : 36-39.

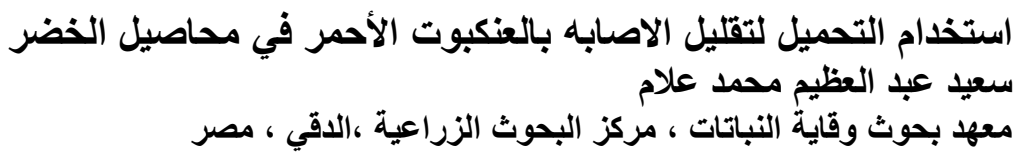

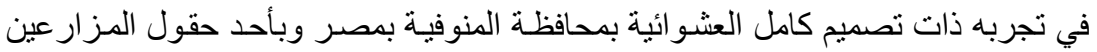

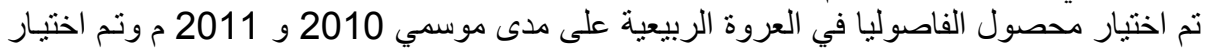

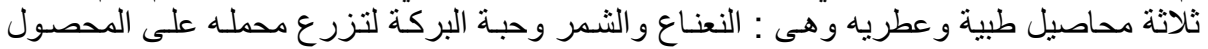

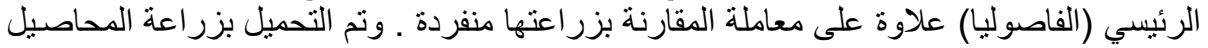

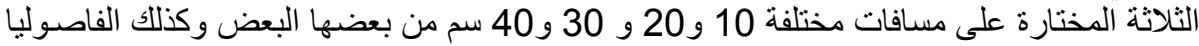

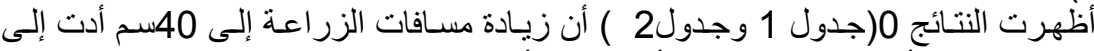

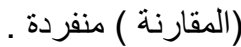

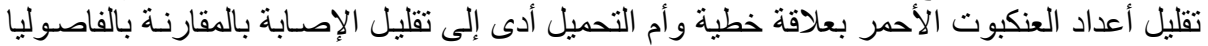

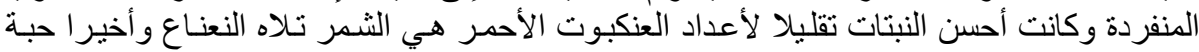

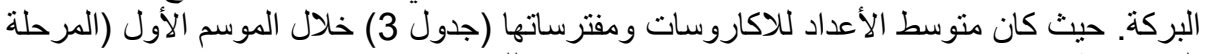

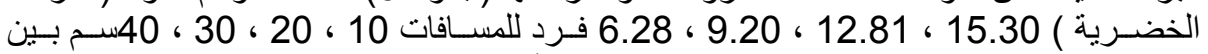

النباتات على الترتيب وكانت ذات فرق معنوي وقد تأكد ذلك خلال الموسم الثاني (مرحلة النمو

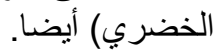

كلية الزراعة - جامعة المنصورة

قام بتحكيم البحث

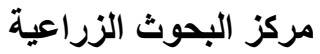

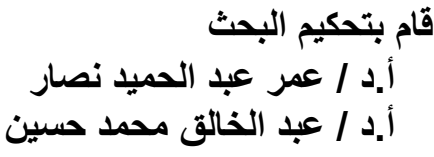


Table (1): Mean number of different stages of $T$. urticae and predators during the first season in Phasouleus vulgares intercropped on 3 medicinal crops grown on different spaces.

\begin{tabular}{|c|c|c|c|c|c|c|c|c|c|c|c|c|c|c|c|c|c|c|}
\hline \multirow{3}{*}{ Stage } & \multirow{3}{*}{ Trt } & \multirow{3}{*}{ Count } & \multicolumn{16}{|c|}{ Spacing } \\
\hline & & & \multicolumn{4}{|c|}{40} & \multicolumn{4}{|c|}{30} & \multicolumn{4}{|c|}{20} & \multicolumn{4}{|c|}{10} \\
\hline & & & Pred & Egg & Imm & Adult & Pred & Egg & Imm & Adult & Pred & Egg & Imm & Adult & Pred & Egg & Imm & Adult \\
\hline \multirow{8}{*}{ Growth } & \multirow{2}{*}{ Control } & Mean & 0.43 & 16.00 & 15.2 & 15.87 & 0.33 & 34.17 & 720.60 & 25.13 & 0.47 & 61.23 & 34.57 & 34.73 & 0.83 & 69.37 & 47.87 & 8.17 \\
\hline & & SD & 0.50 & 4.69 & 3.48 & 2.83 & 0.66 & 8.29 & 5.74 & 7.84 & 0.73 & 13.29 & 13.29 & 8.72 & 75 & 16.81 & 15.46 & 77 \\
\hline & \multirow[b]{2}{*}{ Mint } & Mean & 0.46 & 6.21 & 6.75 & 5.08 & 0.46 & 9.33 & 6.79 & 5.38 & 0.54 & 12.67 & 7.29 & & 71 & .50 & 92 & 04 \\
\hline & & SD & \begin{tabular}{|l|l|}
0.51 \\
\end{tabular} & 2.62 & 2.47 & 1.82 & 0.59 & \begin{tabular}{|l|}
4.07 \\
\end{tabular} & 2.99 & 2.00 & \begin{tabular}{|l|l|}
0.66 \\
\end{tabular} & \begin{tabular}{|l|}
3.80 \\
\end{tabular} & \begin{tabular}{|l|}
1.78 \\
\end{tabular} & 39 & 81 & \begin{tabular}{|l|}
2.34 \\
\end{tabular} & 30 & 5 \\
\hline & \multirow{2}{*}{ Fennel } & Mean & 0.38 & 6.42 & 5.17 & 3.04 & 0.50 & 6.00 & 5.38 & 3.21 & \begin{tabular}{|l|l|}
0.54 \\
\end{tabular} & 5.46 & \begin{tabular}{|l|}
4.25 \\
\end{tabular} & 92 & 71 & 4 & 54 & 67 \\
\hline & & SD & 0.65 & 3.45 & 3.20 & 1.97 & 0.59 & 3.65 & 3.03 & 1.72 & 0.59 & 3.24 & 2.31 & 1.72 & .75 & 3.50 & 2.78 & 2.50 \\
\hline & \multirow{2}{*}{ Black } & Mean & \begin{tabular}{|l|}
0.67 \\
\end{tabular} & 6.33 & 4.08 & 2.88 & 0.88 & 7.71 & 6.29 & 4.25 & 0.79 & 6.29 & \begin{tabular}{|l|}
4.67 \\
\end{tabular} & 3.17 & .75 & \begin{tabular}{|l|}
6.88 \\
\end{tabular} & 4.08 & 2.00 \\
\hline & & SD & 0.70 & 2.73 & 1.93 & 1.48 & 0.80 & 3.86 & 2.96 & 2.49 & 0.93 & 3.06 & 2.76 & .49 & .68 & 2.77 & 2.30 & 1.18 \\
\hline \multirow{8}{*}{ Fruiting } & \multirow{2}{*}{ Control } & Mean & 0.27 & 16.60 & 17.2 & 17.83 & 0.20 & 32.83 & 321.90 & 20.00 & 0.37 & 58.10 & 33.13 & 32.10 & 1.53 & 62.07 & 45.50 & 41.60 \\
\hline & & SD & 0.52 & 2.87 & 2.95 & 2.80 & 0.41 & 8.04 & 5.79 & 3.32 & 0.61 & 12.34 & \begin{tabular}{|l|}
7.95 \\
\end{tabular} & 5.96 & 1.11 & 18.12 & 14.32 & 17.93 \\
\hline & \multirow{2}{*}{ Mint } & Mean & 0.46 & 6.21 & 6.75 & 5.08 & 0.46 & 9.33 & 6.79 & 5.38 & 0.54 & 12.67 & 7.29 & 5.50 & 0.71 & 11.50 & 6.92 & 4.04 \\
\hline & & SD & 0.51 & 2.62 & 2.47 & 1.82 & 0.59 & 4.07 & 2.99 & 2.00 & 0.66 & 3.80 & 1.78 & 1.89 & 0.81 & 2.34 & 3.30 & 2.05 \\
\hline & \multirow{2}{*}{ Fennel } & Mean & 0.44 & 6.60 & 5.32 & 3.08 & 0.52 & 6.00 & 5.40 & 3.28 & 0.56 & 5.60 & 4.32 & 3.00 & 0.76 & 6.72 & 4.56 & 3.72 \\
\hline & & SD & 0.71 & 3.50 & 3.22 & 1.93 & 0.59 & 3.57 & 2.97 & 1.72 & 0.58 & 3.25 & 2.29 & 1.73 & 0.78 & 3.54 & 2.72 & 2.46 \\
\hline & \multirow{2}{*}{ Black } & Mean & 0.67 & 6.33 & 4.08 & 2.88 & 0.88 & 7.71 & 6.29 & 4.25 & 0.79 & 6.29 & 4.67 & 3.17 & 0.75 & 6.88 & 4.08 & 2.00 \\
\hline & & $\overline{7}$ & 0.70 & 2.73 & 1.93 & 1.48 & 0.80 & 3.86 & 2.96 & 2.49 & 0.93 & 3.06 & 2.76 & 1.49 & 0.68 & 2.77 & 2.30 & 1.18 \\
\hline
\end{tabular}


Table (2): Mean number of different stages of T.urticae and predators during the second season in Phasouleus vulgares intercropped on 3 medicinal crops grown on different spaces.

\begin{tabular}{|c|c|c|c|c|c|c|c|c|c|c|c|c|c|c|c|c|c|c|}
\hline \multirow{3}{*}{ Stage } & \multirow{3}{*}{ Trt } & \multirow{3}{*}{ Count } & \multicolumn{16}{|c|}{ Spacing } \\
\hline & & & \multicolumn{4}{|c|}{40} & \multicolumn{4}{|c|}{30} & \multicolumn{4}{|c|}{20} & \multicolumn{4}{|c|}{10} \\
\hline & & & Pred & Egg & Imm & Adult & Pred & Egg & Imm & Adult & Pred & Egg & Imm & Adult & Pred & Egg & Imm & Adult \\
\hline \multirow{8}{*}{ Growth } & \multirow{2}{*}{ Control } & Mean & 0.13 & 15.17 & 14.17 & 13.67 & 0.33 & 26.80 & 19.20 & 18.27 & 0.57 & 55.13 & 37.67 & 32.77 & 0.83 & 74.90 & 52.37 & 56.00 \\
\hline & & SD & 0.35 & 3.11 & 1.91 & 1.84 & 0.55 & 6.09 & 3.72 & 4.47 & 0.73 & 14.77 & 7.53 & 9.68 & 1.18 & 17.20 & \begin{tabular}{|l|}
9.89 \\
\end{tabular} & 15.20 \\
\hline & \multirow{2}{*}{ Mint } & Mean & 0.33 & 4.63 & 5.15 & 4.48 & 0.11 & 6.78 & 6.63 & 5.26 & 0.63 & 13.11 & 11.30 & 12.04 & 0.26 & 14.78 & 13.07 & 12.74 \\
\hline & & SD & 0.48 & 1.69 & 1.92 & 1.93 & 0.32 & 1.60 & 2.48 & 1.99 & 0.79 & 3.24 & 1.79 & 2.72 & 0.53 & 3.18 & 2.46 & 2.90 \\
\hline & \multirow{2}{*}{ Fennel } & Mean & 0.63 & 2.54 & 2.33 & 2.00 & 0.38 & 3.96 & 3.92 & 2.75 & 0.42 & 3.00 & 3.00 & 1.83 & 0.50 & 3.13 & 2.79 & 1.92 \\
\hline & & SD & 0.88 & 1.35 & 1.43 & 1.02 & 0.65 & 2.66 & 2.00 & 1.59 & 0.58 & 1.79 & \begin{tabular}{|l|}
1.82 \\
\end{tabular} & 1.31 & 0.66 & 1.54 & 1.28 & 1.41 \\
\hline & \multirow{2}{*}{ Black } & Mean & 0.38 & 5.79 & 4.92 & 3.88 & 0.33 & 8.75 & 6.83 & 4.96 & 0.38 & 11.50 & 7.50 & 6.46 & 0.13 & 6.67 & 8.04 & 6.67 \\
\hline & & SD & 0.58 & 1.67 & 1.44 & 1.15 & 0.56 & 1.82 & 1.61 & 1.37 & 0.58 & 3.56 & 2.00 & 1.77 & 0.34 & 2.97 & 3.00 & 1.88 \\
\hline \multirow{8}{*}{ Fruiting } & \multirow{2}{*}{ Control } & Mean & 0.47 & 16.63 & 12.70 & 13.83 & 0.47 & 24.63 & 22.27 & 21.50 & 0.53 & 51.07 & 36.00 & 34.13 & 0.87 & 57.20 & 47.60 & 46.93 \\
\hline & & SD & 0.78 & 3.74 & 1.90 & 2.98 & 0.63 & 6.99 & 4.41 & 4.22 & 0.68 & 16.16 & 5.27 & 6.76 & 0.57 & 18.54 & 11.45 & 16.59 \\
\hline & \multirow{2}{*}{ Mint } & Mean & 0.81 & 6.41 & 5.89 & 4.81 & 0.26 & 6.04 & 6.15 & 5.41 & 0.70 & 12.52 & 10.63 & 11.00 & 0.22 & 16.00 & 15.52 & 17.48 \\
\hline & & SD & 0.79 & \begin{tabular}{|l|}
1.74 \\
\end{tabular} & 2.10 & 1.73 & 0.53 & 2.10 & 1.66 & 1.82 & 0.67 & \begin{tabular}{|l|}
4.97 \\
\end{tabular} & 2.22 & 2.77 & 0.51 & 5.36 & 3.20 & 3.96 \\
\hline & \multirow{2}{*}{ Fennel } & Mean & 0.37 & \begin{tabular}{|l|}
1.97 \\
\end{tabular} & 2.90 & 2.67 & 0.20 & 3.03 & 3.43 & 3.50 & \begin{tabular}{|l|}
0.33 \\
\end{tabular} & 6.73 & \begin{tabular}{|l|}
5.77 \\
\end{tabular} & 4.13 & 0.30 & \begin{tabular}{|l|}
6.73 \\
\end{tabular} & \begin{tabular}{|l|}
6.07 \\
\end{tabular} & 4.93 \\
\hline & & SD & 0.61 & 1.94 & 1.90 & 1.37 & 0.55 & 1.94 & 1.94 & 1.68 & 0.61 & 1.66 & 1.50 & 1.17 & 0.53 & 2.18 & 1.87 & 1.62 \\
\hline & \multirow[b]{2}{*}{ Black } & Mean & 0.37 & 6.81 & 6.22 & 4.15 & 0.33 & 7.70 & 8.63 & 7.81 & \begin{tabular}{|l|}
0.22 \\
\end{tabular} & 14.11 & 12.37 & 13.00 & 0.30 & 19.19 & 14.85 & 9.07 \\
\hline & & SD & 0.74 & 1.88 & \begin{tabular}{|l|}
1.58 \\
\end{tabular} & 1.32 & 0.62 & 1.84 & 1.98 & 2.15 & \begin{tabular}{|l|}
0.42 \\
\end{tabular} & 3.31 & 3.30 & 3.46 & 0.54 & 4.29 & 3.90 & 2.37 \\
\hline
\end{tabular}

